\title{
Determinants of Attrition in Call Centers: a study of Indian Call Centers
}

\author{
Younis Ahamd Shah, Dr. Riyaz Ahmad Rainayee \\ Research scholar, department of business and financial studies, University of Kashmir \\ Associate Professor, department of business and financial studies, University of Kashmir
}

With the advent of 21 st century the call centers have become an important auxiliary service centers to many business organizations. High level of attrition rate hampers the growth of call center industry. This study attempts to understand the reasons behind the high attrition rate in Indian call center industry. Results of regression analysis reveal that among various hypothesized determinants of attrition, "job insecurity" and "Low Promotional Chances" significantly contribute to high attrition rate in call centers. On the basis of results of this study some suggestions have been put forth for the minimization of attrition levels in call centers.

\section{Introduction}

Towards the end of the 20th century business organizations grew beyond the boundaries of nations and became global. Thus in order to support its wide base of customers the need of call center became imperative. Now big organizations outsource business processes to highly specialized organizations meant for providing these services called BPO's. The BPO industry has grown up dramatically worldwide, particularly in India "Information Technology (IT) and Business Process Outsourcing (BPO) sector revenues (excluding hardware) were US\$ 109 billion in the year 2013-14, generating direct employment for nearly 3.1 million persons and indirect employment of around 10 million. And as a proportion of national GDP, IT and BPO sector revenues have grown from $1.2 \%$ in financial year $1997-98$ to an estimated $8.1 \%$ in financial year 201314." (NASSCOM, 2014). In 2013-14, as per National Association of Software and Services Companies (NASSCOM, 2012) estimates, IT and BPO export revenues to touch USD 118 billion in FY2014, growing by 8.8 per cent over FY2013. These estimates incline to indicate the growth trend in this sector. Call centers in India are providing a host of IT enabled services, such as, helpdesk services, marketing services, accounting services, remote network management, to mention a few. Call centers in India offer cost-effective outsourcing services without compromising on quality. India is the world largest supplier of employable human capital - 5.3 million graduates in FY2014 with Flat entry level salaries, flattening employee pyramid, Tier II/III service delivery, alternate talent pool hiring and fast career growth helping India stay 7-8X cheaper than source locations and 30 per cent cheaper than the next nearest low-cost country.

One of the biggest problems faced by call center industry is high level of employee turnover;different sources highlight different turnover rates in Indian call center industry. It is reported to be anywhere between 20-70 percent however, NASSCOM reported it to be $15-25 \%$. Similar observations are made by Associated Chambers of Commerce and Industry of India (ASSOCHAM), that is "the level of attrition of this industry has come down to $15-20 \%$ in the last six months (Jan-June) for the year 2012 when compared to the 55-60\% attrition rate in same period during the year 2011" (The Economic Times, 2012). Some researchers have argued that the turnover rates are higher than reported by company officials (Singh, 2005; Taylor and Bain, 2005), and turnover still remains to be a major problem for the industry.

There is a cost associated with voluntary employee turnover viz hiring, training \& developing new employee and the cost associated with the dip in productivity due to loss of an experienced employee. According to a research conducted by In 2008, the National Association of Call Centers in the United States estimated that the cost of replacing a contact centre worker was \$5,566. (Contact Center Canada, 2009) that doesn't include the biggest cost in terms of reduced customer satisfaction and business because of inexperienced agents. Therefore, employee turnover is one of the biggest problems confronted by call centers and it does have a huge impact on the cost and the quality of services. The critics regard call centers as large service factories which provide poor quality jobs, with high level of workload, low wages, promotion chances and job security. These practices are adopted to remain cost- effective to clients, but at the same time these practices are believed to be determinants of employee turnover in call centers (Ashford, Lee \&Bobko, 1989), (Stanworth, 2000) and (Taylor and Bain, 1999a). 


\section{Review of literature}

\section{Lack of Job Security as a significant predictor of Turnover Intention}

Leaving the organization in search of more secure career opportunities is common among employees who feel insecure about their jobs (Ashford, Lee \&Bobko, 1989). Due to lack of job security organisations may consequently lose their most valuable employees, the ones they most want to retain (Ashford et al., 1989). The result of increased turnover is an increased cost in terms of the recruitment and training of new employees. The association between Job Security and intention to leave has been observed in previous studies (Burke, 1998; Mauno et al., 2001).

I.U. Zeytinoglu et al., (2013), examines the association between perceived job security and job satisfaction, commitment and turnover intention of 162 bank call center employees from Istanbul Turkey. Results of multivariate analyses show that perceived job security is associated with job satisfaction, commitment and turnover intention in the organization. The effect of job security on turnover intention is mediated through job satisfaction, which in turn is mediated through organizational commitment.

Karen O'quin and Sandra Lotempio (1998) conducted a study to measure the overall job satisfaction and turnover intention in service sector of Buffalo New York. The multivariate analysis of varience indicate that ratings of Job Security were significantly related to job dissatisfaction which in turn is related with turnover intention.

\section{Low of Promotional Chances as a significant predictor of Turnover Intention}

The lack of career path available to agents is one of the most frequently cited causes of employee turnover in call centres (Belt, 2001; Korczynski, 2001). Belt (2001), amongst others (Stanworth, 2000; Taylor and Bain, 1999a) argue that call centres are relatively 'careerless'

\section{Poor Salary as a significant predictor of Turnover Intention}

When looking for employment, most of the people if not all, choose to go for something that promises a fat pay cheque. Lower pay leads to lower satisfaction and thereby intention to seek a job which offers a higher pay. Research has revealed that pay level is negatively associated with turnover intention in call centers.

A study conducted by Catriona Wallace et al. (2004) investigated the high levels of front-line staff attrition in call centres in order to understand what aspects of the workplace, which are within the control of management, influence subordinate turnover. The results reveal that there is a negative correlation between pay and turnover intention.

Crone, et al (2001) conducted a study to analyse the compensation strategies of Australian call centers and the results report a significant negative relationship between employees' pay rates and turnover.

\section{Rationale of the Study}

In call centers, Customer Service Representatives (CSRs) are of significant importance for the delivery of services to the customers (Singh, Goolsby\& Rhoads, 1994).Numerous studies have been conducted to find out the cause ofemployee turnover, and these studies came up with varied results on this issue. In this background, this study investigates the reasons behind the Turnover Intention of employees in call centers in Indian context.

\section{Objectives of the Study:}

1. To ascertain the level of intention to quit among call center employees.

2. To explore the sources of turnover intention experienced by call center employees.

3. To suggest on the basis of the results of the study coping strategies for minimization of turnover of call center employees.

\section{Hypothesis:}

On the basis of the available literature following hypothesis were formulated.

H1: Lack of Job Security is a significant predictor of turnover intention.

H2: Poor Salary is a significant predictor of turnover intention

H3: Lack of Promotional chances significantly predict turnover intention 


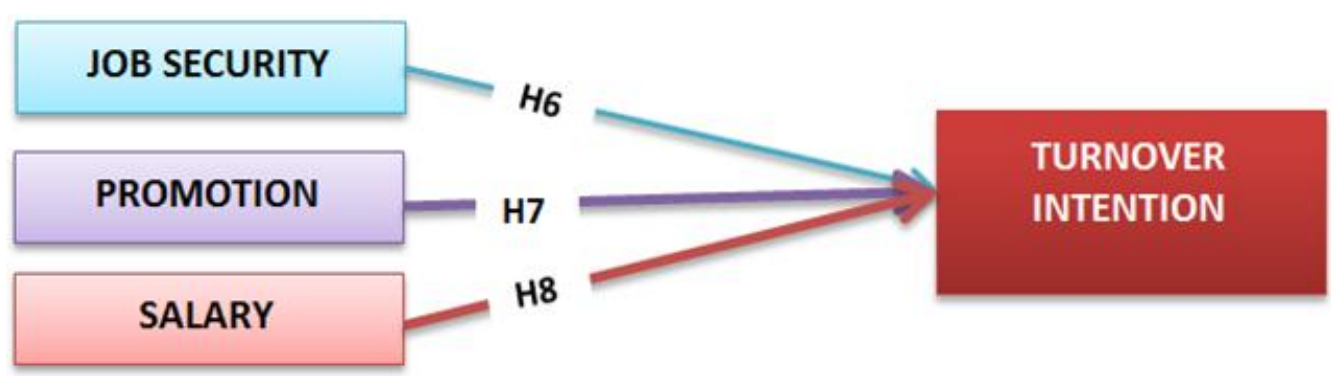

III. Methodology

Job Security was measured by using (De Witte, 2000)"Job Security Questionnaire".Salary was measured by using Smith K.W. (1974) "Job Descriptive Index". Promotion was measured using "Job Descriptive Index" developed by Smith K.W. 1974". Turnover Intention was measured by using "Michigan Organizational Assessment Questionnaire developed by (Cummannetal, 1979). Responses were recorded on 5 point likert type scale.

\section{Survey}

Total of 400 questionnaires were distributed, however only305 questionnaires were fully filled and found to be usable. Among them 212 were males and 93 were females, which points towards the male dominance ofIndian call center industry. Majority of the respondents were graduates i.e. 188 out of 305 and $10+2$ and post graduates were 51 and 66 respectively. Most of the respondents we surveyed were engaged in inbound nature of job i.e. 241 and only 64 were in outbound jobs. Age of the most of the respondents i.e. 190 were found to be 20-25 years, 79 respondents were falling in the age group of 25-30 years and 36 respondents were below 20 years of age.

\section{Results:}

The in-depth analysis Turnover Intention and various dimensions related to turnover intention reveal the following findings see Table (1) :-

\section{Turnover Intention:}

$>$ The study reveals the overall average of quitting intention of call center employees is high i.e. 3.55 on a 5 point scale. And this is in accordance with the industry norm.

$>$ There is no significant difference between the male and female employees in this regard.

> Employees with 10/10+2 and post-graduation educational qualifications are reporting to have higher quitting intentions as compared to graduates. In this regard it is observed that employees with post-graduation qualifications have wide range of employment options available with them and they can easily switch from one job to another, but if they are given specified promotional path and if the feel their positions are secure the results may change the other way. Those with $10 / 10+2$ qualification are usually those who aspire to go for higher education and the same is reflected by the respondents, here it seems to be a problem of hiring policy,before hiring such people their aspirations must be observed.

$>$ Employees working in inbound jobs are having higher quitting intentions in comparison to outbound. Here it may be noted that the people working in outbound operations are supposed to make calls to a targeted segment of people in a specified manner, and with a specific purpose and the responses from the targeted people is easily predictable. While in case of people working in inbound operations there is always a contingency situation and here it is difficult predict what may be the queries of the next caller, this may prove to be frustrating and thus lead to higher quitting intentions, and employee's rotation around outbound and inbound operations could minimize the gap.

$>$ There is no significant difference in quitting intention between various groups of employees of different age groups, thus it can be derived that people at every age group have almost equal quitting intentions

> The results reveal that people with higher working experience tend to show lower quitting intentions, as the days on the job passes the expertise in the job improves and this is the reason why people with higher working experience tend to show lower quitting intentions.

Table 1: Turnover intention on the basis of demographic variables

\begin{tabular}{|l|l|l|l|l|l|} 
Turnover Intention & $\mathbf{N}$ & $\mathbf{M}$ & $\mathbf{S D}$ & $\mathbf{t} / \mathbf{F}$ & $\mathbf{p}$ \\
\hline
\end{tabular}


Determinants of Attrition in Call Centers: A study of Indian Call Centers

\begin{tabular}{|c|c|c|c|c|c|}
\hline Composite Score & 305 & 3.55 & 0.85 & & \\
\hline Gender : & 212 & 3.52 & 0.86 & \multirow{2}{*}{0.88} & \multirow{2}{*}{0.37} \\
\hline Female & 93 & 3.62 & 0.84 & & \\
\hline E. Qualification : $10^{\text {th }}$ or $10+2$ & 51 & 3.79 & 0.91 & \multirow{3}{*}{4.11} & \multirow{3}{*}{0.01} \\
\hline Graduate & 188 & 3.44 & 0.89 & & \\
\hline $\begin{array}{l}\text { Post Graduate } \\
\text { or higher }\end{array}$ & 66 & 3.66 & 0.65 & & \\
\hline Type of Job : & 241 & 3.70 & 0.84 & \multirow{2}{*}{6.27} & \multirow{2}{*}{0.00} \\
\hline Outbound & 64 & 2.98 & 0.63 & & \\
\hline Below 20 years & 36 & 3.83 & 0.71 & \multirow{3}{*}{2.97} & \multirow{3}{*}{0.05} \\
\hline $20-25$ years & 190 & 3.59 & 0.84 & & \\
\hline $25-30$ years & 79 & 3.42 & 0.85 & & \\
\hline W. Experience : Less than 6 month & 65 & 3.56 & 0.92 & \multirow{4}{*}{15.35} & \multirow{4}{*}{0.00} \\
\hline 6 months to 1 year & 82 & 3.95 & 0.88 & & \\
\hline 1 to 2 years & 74 & 3.59 & 0.71 & & \\
\hline Above 2 Yrs & 84 & 3.11 & 0.68 & & \\
\hline
\end{tabular}

Table 2: Correlation between Turnover Intention and its constructs

\begin{tabular}{|c|c|c|c|c|}
\hline & $\begin{array}{l}\text { TURNOVER } \\
\text { INTENTION }\end{array}$ & JOB SECURITY & SALARY & $\begin{array}{c}\text { PROMO } \\
\text { TION }\end{array}$ \\
\hline $\begin{array}{l}\text { TURNOVER } \\
\text { INTENTION }\end{array}$ & 1 & & & \\
\hline \multirow[t]{2}{*}{ JOB SECURITY } & $-0.373 * *$ & 1 & & \\
\hline & 0.000 & & & \\
\hline \multirow[t]{2}{*}{ SALARY } & $-0.182 * *$ & $0.253 * *$ & 1 & \\
\hline & 0.001 & 0.000 & & \\
\hline \multirow[t]{2}{*}{ PROMOTION } & $-0.345 * *$ & $0.169 * *$ & $0.248 * *$ & 1 \\
\hline & 0.000 & 0.003 & 0.000 & \\
\hline
\end{tabular}

An analysis of data contained in Table 2 reveals that Turnover Intention is negatively correlated with Job Security $(\mathrm{r}=-0.373 * *)$, Salary $(\mathrm{r}=-0.182 * *)$ \& Promotion $\left(\mathrm{r}=-0.345^{* *}\right)$ which indicates that any improvement in the Job Security, salary and promotion will result in decline in quitting intentions of employees. Since all the independent variables were found to be associated with the Turnover Intention it becomes imperative to understand in depth, which variables is have deeper and significant influence on Turnover Intention, for this purpose regression analysis was carried (see table 3-5) 
Table $3 \mathrm{R}^{2}$ value shows that $30 \%$ of the variation in turnover intention is explained by turnover intention factors (i.e. Job stress, job security, salary and promotion). The significance of model in terms of overall fit is expressed by $\mathrm{F}=32.67$ (see table 4 ). The Beta values (Table5) of job security 0.195 and promotion 0.257 respectively shows that there is a significant $(\mathrm{p}<0.05)$ and positive impact of twofactors on turnover intention. However, the Beta value of salary i.e. 0.064 reveals there is no significant ( $p>0.05)$ impact of salary on turnover intention. In other words the job security and promotion are much useful to predict the turnover intention of call center employees as compared to salary.

Table 3: Model Summary

\begin{tabular}{|c|c|c|c|}
\hline \multicolumn{4}{|c|}{ Model Summary } \\
\hline $\begin{array}{c}\text { Mod } \\
\text { el }\end{array}$ & $\mathbf{R}$ & $\begin{array}{c}\mathbf{R} \\
\text { Square }\end{array}$ & Adjusted R Square $^{\mathrm{b}}$ \\
\hline 1 & $.551^{\mathrm{a}}$ & .303 & .294 \\
\hline $\begin{array}{l}\text { a. Predictors: (Constant), PROMOTION, SALARY, } \\
\text { JOBSECURITY }\end{array}$ \\
\hline
\end{tabular}

Table 4 : Analysis of Variance

\begin{tabular}{|c|c|c|c|c|c|c|}
\hline \multicolumn{7}{|c|}{ ANOVA $^{b}$} \\
\hline \multicolumn{2}{|c|}{ Model } & $\begin{array}{c}\text { Sum of } \\
\text { Squares }\end{array}$ & df & $\begin{array}{c}\text { Mean } \\
\text { Square }\end{array}$ & $\overline{\mathbf{F}}$ & Sig. \\
\hline \multirow[t]{3}{*}{1} & $\begin{array}{l}\text { Regressio } \\
\mathbf{n}\end{array}$ & 68.113 & 4 & 17.028 & 32.672 & $.000^{\mathrm{a}}$ \\
\hline & Residual & 156.356 & 300 & .521 & & \\
\hline & Total & 224.468 & 304 & & & \\
\hline \multicolumn{7}{|c|}{ a. Predictors: (Constant), PROMOTION, SALARY, JOBSECURITY } \\
\hline \multicolumn{5}{|c|}{ b. Dependent Variable: TURNOVERINTENTION } & & \\
\hline
\end{tabular}

Table 5: Regression Analysis of Turnover intention and its correlates

\begin{tabular}{|c|c|c|c|c|c|c|}
\hline \multicolumn{7}{|c|}{ Coefficients } \\
\hline \multirow{2}{*}{\multicolumn{2}{|c|}{ Model }} & \multicolumn{2}{|c|}{$\begin{array}{l}\text { Unstandardized } \\
\text { Coefficients }\end{array}$} & \multirow{3}{*}{$\begin{array}{c}\begin{array}{c}\text { Standardize } \\
\text { d } \\
\text { Coefficients }\end{array} \\
\text { Beta } \\
\end{array}$} & \multirow[t]{2}{*}{$\mathbf{t}$} & \multirow[t]{2}{*}{ Sig. } \\
\hline & & $\mathbf{B}$ & Std. Error & & & \\
\hline \multirow[t]{4}{*}{1} & (Constant) & 3.947 & .287 & & 13.745 & .000 \\
\hline & $\begin{array}{l}\text { JOBSECURIT } \\
Y\end{array}$ & -.166 & .046 & -.195 & -3.596 & .000 \\
\hline & SALARY & -.062 & .050 & -.064 & -1.253 & .211 \\
\hline & PROMOTION & -.273 & .053 & -.257 & -5.105 & .000 \\
\hline \multicolumn{4}{|c|}{ a. Dependent Variable: TURNOVERINTENTION } & & & \\
\hline
\end{tabular}

Table 6: Showing Hypothesis Decision

\begin{tabular}{|l|l|l|}
\hline $\mathbf{1}$ & $\begin{array}{l}\text { Lack of Job Security is a significant reason for turnover intention among call } \\
\text { center employees }\end{array}$ & Accepted \\
\hline $\mathbf{2}$ & $\begin{array}{l}\text { Poor Salary is a significant reason for turnover intention among call center } \\
\text { employees }\end{array}$ & Rejected \\
\hline $\mathbf{3}$ & $\begin{array}{l}\text { Lack of Promotional chances is a significant reason for turnover intention } \\
\text { among call center employees }\end{array}$ & Accepted \\
\hline
\end{tabular}

\section{Conclusion}

Thus findings of regression analysis reveal lack of job security and low promotion chances are significant $(\mathrm{p}<0.05)$ predictors of turnover intention and salary is not a significant predictor of turnover intention. This is the reason why call center jobs are often perceived to be career dead ends. Giving agents a 
defined promotion pathway that encourages them to increase their job grade and salaries by providing outstanding performance can dispel this notion. Employees who feel that they have a profitable future with their organization are less likely to quit the job. Regular incentives and recognition should be routine practices in call centers where the staff has the difficult job of customer service every day. Employees will tend to stay where they feel appreciated. Simple recognition of jobs well done in the quarterly newsletter, pictures on the bulletin board, dinner gift certificates, and other small rewards provide a high return on investment. Here it may be noted that in the first part of our questionnaire we asked the respondents why they joined call centre job, among 305 respondents 210 people responded because of a good salary and the results reflect the same i.e. they are fairly satisfied with the salary they are getting and salary is not a significant predictor. Thus in this regard necessary steps must be taken so that the most valuable resource of call center organizations is retained.

\section{References}

[1] Ashford, S.J., Lee, C., \&Bobko, P., (1989). Content, causes, and consequences of job insecurity: A theory-based measure and substantive test. Academy of Management Journal, 32, 803-829.

[2] Belt, V. (2001), 'A Female Ghetto? Women's Careers in Call Centres', Conference Proceedings 'Call Centres and Beyond: The HRM Implications’ Kings College, University of London, November.

[3] Burke, R.J. (1998). Correlates of job insecurity among recent business school graduates. Employee Relations, 20(1), 92-99.

[4] Cammann, C., Fichman, M., Jenkins, D. and Klesh, J. 1979. The Michigan Organizational Assessment Questionnaire. Unpublished Maniscript, University of Michigan, Ann Arbor, Michigan.

[5] Catriona Wallace and Geoff Eagleson (2004). Computer Technology, Leadership and Subordinate Intention to Turnover in Call Centres.International Employee Relations Review, November.

[6] Contact Centre Canada 2009, "Human Resource Trends in the Contact Centre Sector" pp. 8.

[7] De Witte, H. 2000. 'Arbeidsethos en jobonzekerheid: Meting en gevolgenvoorwelzijn, tevredenheid en inzet op het werk'. In Bouwen, R., De Witte, K., De Witte, H. \&Taillieu, T. (Eds.). Van groep to gemeenschap. Leuven: Garant, pp. 1-32.

[8] I. U. Zeytinoglu, GözdeYilmaz, AskinKeser, KivançInelmen, Duygu Uygur and Arzu, (2013) . Job satisfaction, flexible employment and job security among Turkish service sector workers, Economic and Industrial Democracy 34: 123.

[9] Karen O'Quin,;LoTempio, Sandra (1998) Job satisfaction and intentions to turnover in human services agencies perceived as stable, Perceptual \& Motor Skills; Academic Journal Vol. 86 Issue 1, p339.

[10] Korczynski, M. (2001), 'What a Difference a Union Makes: The Impact of Partnership Unionism on Work Organisation in Call Centres', Conference Proceedings 'Call Centres and Beyond: The HRM Implications' Kings College, University of London, November.

[11] Mauno, S., Leskinen, E., \&Kinnunen, U. (2001). Multi-wave, multi-variable models of job insecurity: Applying different scales in studying the stability of job insecurity. Journal of Organizational Behavior, 22, 919-937.

[12] NASSCOM (2014), "The IT-BPO Sector in India Strategic 2014"http://http://survey.nasscom.in/sites/default/files/researchreports/softcopy/Strategic_Review_2014.pdf

[13] Singh, H. (2005a), "Is the BPO Iceberg Melting Under Attrition Heat?",The Economic Times, 10 February.

[14] Singh, J., Goolsby, J. R., \& Rhoads, G. K. 1994. Behavioral and psychological consequences of boundary spanning burnout of customer service representatives. Journal of Marketing Research, 31: 558-569.

[15] Smith, K. W. 1974. "Forming composite scales and estimating their validity through factor analysis." Social Forces 53 (December) 80-168.

[16] Stanworth (2000), 'Women and work in the information age', Gender, Work and Organization, vol. 7, no. 1, pp. $20-32$.

[17] Taylor, P. and Bain, P. (1999a) An Assembly Line in the Head. Work and Employee Relations in the Call Centre. Industrial Relations Journal, 30.2, June 1999, pp. 101-117.

[18] Taylor, P. and Bain, P. (2005), "India Calling to the Far Away Towns: The Call Centre Labour Process and Globalization", Work, Employment and Society, Vol. 19 No. 2, pp. 261-282.

[19] The Economic Times (2012), “Attrition rate declines in Jan-Jun period this year: A Study" (Accessed on 4 August 2012). 